\title{
PENERAPAN METODE EKSPERIMEN DALAM PEMBELAJARAN IPA DI SDN INPRES BUMI BAHARI
}

\author{
Haeroni $^{1)}$ Thalib $^{2)}$ Karmawati $^{2)}$ \\ e-mail: haeroni255@gmail.com \\ ${ }^{1}$ Mahasiswa Program Studi PGMI FTIK Institut Agama Islam Negeri Palu \\ ${ }^{2}$ Dosen Fakultas Tarbiyah Ilmu Keguruan Institut Agama Islam Negeri Palu
}

\begin{abstract}
This research discusses "The Application of Experimental Methods in Science Learning in SDN Inpres Bumi Bahari." By raising the issue: 1. How is the application of experimental methods in learning science in SDN Inpres Bumi Bahari? 2. What are the obstacles to the application of experimental methods in learning science in SDN Inpres Bumi Bahari, and how is the solution to overcome the application of experimental methods in learning science in SDN Inpres Bumi Bahari?. The research used is qualitative research. This study uses data collection techniques through observation, interviews and documentation. While the data analysis technique used is data reduction, data presentation and data verification as well as checking the validity of the data. The results showed that the application of the experimental method in learning science about the photosynthetic material had been carried out several stages, namely: the preparation stage, the implementation stage, and the closing stage. In the preparation phase, the teacher must convey the learning objectives to be achieved. Furthermore, the implementation stage contains an explanation of the material, a demonstration of performance, and photosynthesis observation activities on botanical plants. Finally, the concluding stage contains a repeat of photosynthetic observations of the students that are carried out on botanical plants. There are several obstacles that are found in the application of experimental methods in learning science in SDN Inpres Bumi Bahari, namely: lack of students' attention to the experimental method in learning science, material about photosynthesis in the classroom. The way that can be taken to solve this problem is to invite students to work together in the learning process in the classroom so that students can easily capture and understand the lessons explained by the teacher. This can be done by the teacher to students so that students easily understand and comprehend the learning given and explained by the teacher.
\end{abstract}

Keywords : Experiment Method, IPA Learning

\section{PENDAHULUAN}

Dunia terus mengalami perkembangan yang begitu pesat terutama sejak adanya arus globalisasi. Laju perkembangan tersebut berpengaruh terhadap berbagai 
bidang yang turut berubah dan berkembang sesuai dengan zamannya. Salah satu yang turut berkembang adalah bidang pendidikan.

Pendidikan merupakan salah satu hal penting yang menunjang kehidupan manusia. Pendidikan merupakan kunci utama kemajuan hidup manusia dalam segala aspek. Manusia dan pendidikan ibarat dua sisi mata uang yang tidak dapat dipisahkan. Karena pendidikan merupakan salah satu alat untuk membina dan membentuk kepribadian manusia sesuai dengan nilai-nilai kebudayaan yang berlaku dimasyarakat. Dengan demikian manusia dituntut untuk maju dan berkembang dalam kehidupan, serta memperoleh gagasan atau ide untuk melakukan perubahan dan pengembangan kebudayaan melalui pendidikan. Menurut Undang-undang No. 20 Tahun 2003 tentang sistem Pendidikan Nasional pasal 1 :

Pendidikan adalah usaha sadar dan terencana untuk mewujudkan suasana belajar dan proses pembelajaran agar peserta didik secara aktif mengembangkan keagamaan, pengenalan diri, kepribadian kecerdasan,akhlak mulian, serta keterampilan yang diperlukan dirinya,masyarakat bangsa dan negara. ${ }^{1}$

Sehubungan dengan hal tersebut pengertian pendidikan banyak dikemukakan oleh beberapa pakar pendidikan. Pendidikan merupakan kunci pembangunan sebuah bangsa. Pendidikan diharapkan bisa menjadikan individu dan kelompok masyarakat sebagai warga negara (members of the nation-state) yang baik, sadar akan hak dan kewajibannya di satu sisi, serta dapat mempersiapkan individu dan kelompok masyarakat untuk memasuki pasar tenaga kerja disisi yang lain. ${ }^{2}$

Pendidikan senantiasa menjadi sorotan bagi masyarakat khususnya di Indonesia yang ditandai dengan adanya pembaharuan eksperimen guna terus mencari kurikulum, sistem pendidikan, dan metode pembelajaran yang efektif dan efesien. Berbicara tentang pendidikan berarti berbicara tentang manusia dengan segala aspeknya, Nilai suatu bangsa terletak dari kualitas sumber daya manusia yang menjadi warga negara. Semakin baik kualitas manusianya, semakin memiliki peluang besar semakin pula menuju kemajuan dan kemakmuran, khususnya dalam bidang pendidikan, yang berupaya mencapai masyarakat adil dan makmur baik jasmani maupun rohani. Perlu adanya usaha untuk menciptakan sumber daya manusia yang berkualitas, guna untuk memenuhi kebutuhan pembangunan dewasa dan masa yang akan datang, untuk mencapai hal tersebut, perlu ditumbuhkan pembelajaran yang kuat untuk meraih sesuatu yang dicita-citakan.

Dengan pembelajaran yang kuat diharapkan dapat memacu meningkatkan kualitas dan potensi sumber daya manusia, khususnya prestasi dalam bidang Ilmu Pengetahuan Alam. Pembangunan nasional di bidang pendidikan adalah mengembangkan kompetensi peserta didik agar menjadi manusia yang beriman dan

${ }^{1}$ Anwar Arifin, Memahami Paradigma Baru Pendidkan Nasional Dalam Undang-Undang Sisdiknas, (Jakarta : Ditjen Kelembangan Agama Islam Depag, 2003), h.34

${ }^{2}$ Arif Rohman, Memahami Ilmu Pendidikan, (Yogyakarta: CV. Aswaja Pressindo, 2013),hlm. 4. 
bertakwa kepada Tuhan Yang Maha Esa, serta berakhlak mulia, sehat, berilmu, cakap, kreatif, mandiri, dan menjadi warga negara yang demoktratis serta bertanggung jawab. ${ }^{3}$

Berdasarkan defenisi di atas dapat disimpulkan bahwa pendidikan adalah wadah yang urgen untuk mengembangkan seluruh potensi dalam diri siswa sehingga menjadi manusia yang cerdas dan memiliki ilmu pengetahuan. Sumber daya manusia yang memiliki kecerdasan tinggi, yang ditunjang oleh adanya sikap dan perilaku yang bertakwa kepada Tuhan Yang Maha Esa, serta budi pekerti yang luhur, sangat diharapkan dalam rangka mencapai tujuan nasional. Disisi lain adanya, pengetahuan dan keterampilan, serta pola kepribadian yang mantap dan dinamis, juga dapat membantu tercapainya tujuan nasional yaitu membentuk manusia-manusia bertanggung jawab terhadap pembangunan bangsa. Adapun langkah yang harus ditempuh dalam upaya membantu mewujudkan tujuan di atas adalah dengan menumbuhkan dan membina pembelajaran kepada para pelaku pendidikan, terutama pembelajaran para peserta didik yang merupakan harapan bangsa untuk memacu prestasi dalam segala bidang, agar menjadi generasi-generasi yang siap dalam mengahadapi tantangan masa kini dan masa yang akan datang.

Untuk mencapai perestasi belajar yang maksimal, perlu adanya pembelajaran yang kuat yang ditumbuhkan oleh peserta didik, terutama oleh guru yang sebagai pengajar, agar para peserta didik selalu terdorong untuk mengembangkan potensi yang ada pada diri mereka. Disisi lain dalam diri para peserta didik terdapat kepribadian-kepribadian yang unik dan pasti berbeda satu sama lainnya yang semestinya dapat lebih dikembangkan berubah menjadi robotnisasi ketika peserta didik dijadikan obyek pendidikan. Padahal sesungguhnya mereka adalah makhluk unik yang termulia yang Tuhan ciptakan dengan berbekal akal pikiran, Selayaknya proses pembelajaran jadi lebih hidup sebab ketika manusia berpikir maka merupakan cerminan jiwa dan gambaran kehidupan serta eksistensi kehidupan itu sendiri. Dengan berfikir seperti itu maka sesungguhnya mereka telah memanusiakan manusia, ungkapan ini menggambarkan bahwa sesungguhnya banyak orang yang belum memperlakukan manusia secara manusiawi, maka manusia perlu dimanusiakan lagi agar pendidikan menjadi sebuah kualitas.

Metode merupakan hal yang dapat menunjang pencapaian tujuan pengejaran yaitu dapat meningkatkan hasil belajar, jadi metode dapat dijadikan sebagai alat yang efektif untuk mencapai tujuan pengajaran, Penggunaan metode dalam kegiatan pembelajaran sangat diperlukan untuk mempermudah proses pembelajaran yang optimal. Metode mengajar sebagai upaya mencapai tujuan, dengan demikian diperlukan pengetahuan tentang tujuan itu sendiri. Perumusan tujuan yang sejelasjelasnya merupakan persyaratan terpenting sebelum seseorang dan menentukan dan memilih metode mengajar yang tepat, karena kekaburan dalam tujuan yang hendak dicapai akan menyebabkan kesulitan dalam menentukan dan memilih metode yang

${ }^{3}$ Mahfudin Salahudin, Metodologi Pendidikan Agama (Cet; Ke II. Surabaya: Bina Ilmu.2001), 29 
tepat. Apa yang dituju oleh suatu program bidang studi melalui unit pembelajaran, semua termasuk dalam ruang lingkup dari metodologi. Dalam pembelajaran IPA, kita harus berusaha agar peserta didik dapat mengalami maksud dan makna IPA oleh karena itu seorang pendidik harus menetukan metode yang akan di gunakan dalam proses pembelajaran dan relevan dengan materi yang di ajarkan.

Sedangkan kebanyakan pendidikan yang ada di Indonesia belum menyentuh tatanan praktis yang dapat menciptakan suasana belajar yang nyaman dan menyenangkan bagi sasarannya. Oleh karena itu, dalam mencapai tujuan pendidikan yang diinginkan maka sangat perlu pemilihan dan penggunaan metode yang tepat dalam pembelajaran, kiranya dapat meningkatkan pemahaman peserta didik dalam pembelajaran khususnya IPA. Salah satu metode yang tepat diterapkan dalam pembelajaran IPA adalah metode-metode eksperimen. Metode-metode eksperimen sebagai bagian yang integral dalam proses pembelajaran IPA yang amat berguna dalam rangka memperoleh pengalaman secara lansung, dan dengan di terapkannya metode tersebut peserta didik dapat merespon, menerima, memahami serta merealisasikan materi yang di ajarkan sehingga ada inovasi-inovasi baru yang di peroleh pada mata pelajaran IPA. Selain itu setiap metode memiliki beberapa kelebihan dan keunggulan dalam proses pembelajran IPA.

Beberapa uraian latar belakang masalah yang selanjutnya menjadi acuan dalam pembahasan berikutnya dengan menggunakan refensi yang cukup untuk dikaji secara detail dan mendalam. Melihat kenyataan ini, maka penulis termotivasi untuk meneliti secara ilmiah dan akademis tentang Penerapan Metode Eksperimen Dalam Pembelajran IPA di SDN Inpres Bumi Bahari.

\section{METODE PENELITIAN}

Adapun jenis penelitian ini merupakan penelitian kualitatif. Penelitian kualitatif (qualitative research), adalah suatu penelitian yang ditujukan untuk mendeskripsikan dan menganalisis fenomena, peristiwa, aktivitas sosial, sikap, kepercayaan, persepsi, pemikiran orang secara individual maupun kelompok. Beberapa deskripsi digunakan untuk menemukan prinsip-prinsip dan penjelasan yang mengarah pada penyimpulan. Penelitian kualitatif bersifat induktif, peneliti membiarkan permasalahan-permasalahan muncul dari data atau dibiarkan terbuka untuk interpretasi. Data dihimpun dengan pengamatan yang seksama, mencakup deskripsi dalam konteks yang mendetail disertai catatan-catatan hasil wawancara yang mendalam, serta hasil analisis dokumen dan catatan-catatan. ${ }^{4}$

Senada dengan uraian di atas, oleh Matthew B.Miles dan A.Michael Huberman: singkatnya, hal-hal apa yang terdapat dalam analisis kualitatif ? pertama, data itu muncul berwujud kata-kata dan bukan angka. Data mungkin telah dikumpulkan dalam aneka macam cara (observasi, wawancara, intisari dokumen, pita

\footnotetext{
${ }^{4}$ Nana Syaodih Sukmadinata, Metode Penelitian Pendidikan( Cet. 8: Bandung: Pt Remaja Rosdakarya, 2012), 60
} 
rekaman) dan biasanya "diproses " kira-kira sebelum siap digunakan (melalui pencatatan, pengetikan, penyunting atau ahli tulis), tetapi analisis kualitatif tetap menggunakan kata-kata, yang biasanya disusun dalam teks yang diperluas. ${ }^{5}$

Penelitian kualitatif mendapatkan masalah dengan cara induktif. Peneliti harus datang ke latar penelitian, berada di sana dalam waktu yang memadai dan menggali masalah menggunakan cara berinteraksi dengan para partisipan yaitu subjek pemilik realitas yang akan diteliti. Karena itu masalah dalam penelitian kualitatif tidak digali dan dirumuskan secara deduktif sebagaimana yang lazim dilakukan dalam penelitian kuantitatif. Itu berarti masalah dalam penelitian kualitatif tidak berasal atau diturunkan dari konsep dan teori. Juga tidak berasal dari pemikiran dan kehendak si peneliti.

Si peneliti kualitatif harus menggali masalah penelitian dari latar penelitian. Ia harus datang ke tempat pendidikan berlangsung, ke sekolah, ke kelas, ke laboratorium, ke bengkel kerja. Peneliti hadir ke tempat proses pendidikan dan proses pembelajaran berlangsung. Ia bukan saja melakukan observasi yang terjarak, tetapi juga melakukan observasi atau pengamatan pertisipatif yang mengharuskan ia terlibat secara aktif. Tidak cukup sampai disitu.

Si peneliti juga harus melakukan wawancara mendalam untuk menggali lebih dalam apa yang ditemukanya selama pengamatan partisipatif. Dengan cara inilah si peneliti mencaritemukan dan merumuskan masalah penelitian. ${ }^{6}$

Sugiono dalam bukunya mengutip pendapat Bogdan dan Biklen yang mengatakan tentang karakteristik penelitian kualitatif meliputi

1. Dilakukan pada kondisi yang alamiah, langsung ke sumber data dan peneliti adalah instrumen kunci

2. Penelitian kualitatif lebih bersifat deskriptif. Data yang terkumpul berbentuk katakata atau gamabar, sehingga tidak menekankan pada angka

3. Penelitian kualitatif lebih menekankan pada proses dari pada produk atau outcome

4. Peneliti kualitatif melakukan analisis data secara induktif

5. Peneliti kualitatif lebih menekankan makna. ${ }^{7}$

Dengan demikian, peneliti menggunakan jenis penelitian kualitatif yakni peneliti banyak menitikberatkan kepada kegiatan penelitian di lokasi objek penelitian yaitu di sekolah SDN Inpres Bumi Bahari. Penelitian ini dirancang dan diarahkan dengan menggunakan langkah-langkah yang disusun secara terencana dan sistematis guna mendapatkan jawaban-jawaban terhadap pertanyaan-pertanyaan dan memecahkan masalah-masalah tertentu, agar penelitian yang dilakukan mempunyai bobot yang cukup memadai dan dapat memberikan kesimpulan yang tidak merugikan.

\footnotetext{
${ }^{5}$ Matthew B.Miles dan A.Michael Huberman,Analisis data kualitatif,buku tentang metode-metode baru (Jakarta: Ui-Press 1992), h.15-16.

${ }^{6}$ Nana Syaodih Sukmadinata, Metode Penelitian Pendidikan( Cet. 8: Bandung: Pt Remaja Rosdakarya, 2012), 42

${ }^{7}$ Sugiono, Metode Penelitian Pendidikan (Cet. 20; Bandung: Alfabeta, 2014), 22.
} 
Alasan lain peneliti menggunakan penelitian kualitatif didasarkan pada judul penelitian yang dimana mengarah pada penelitian kualitatif serta data-data yang dikumpulkan adalah berupa kata-kata, gambar atau dokumen lain dan peneliti juga bertatap muka secara langsung dengan informan, sehingga dalam hasil penelitian ininantinya uraian hasil penlitian akan berisi kutipan-kutipan data untuk memberikan gambaran yang berkaitan pada masalah pengelolaan belajar di sekolah SDN Inpres Bumi Bahari.

Cara terbaik yang perlu di tempuh dalam penentuan lapangan penelitian ialah dengan jalan mempertimbangkan teori subtantif dan dengan mempelajari serta mendalami fokus serta rumusan masalah penelitian. Untuk itu pergilah dan jejakilah lapangan untuk melihat apakah terdapat kesesuaian dengan kenyataan yang ada di lapangan.

Lokasi yang di maksud dalam penelitian ini adalah SDN Inpres Bumi Bahari. Peneliti memilih SDN Inpres Bumi Bahari, sebagai lokasi penelitian, di karenakan keadaan sekolah tersebut berada di lingkungan masyarakat dan mudah dijangkau peneliti.

Penulis sebagai peneliti di lokasi penelitian bertindak sebagai instrument penelitian dalam pengumpulan data. S. Margono mengemukakan bahwa kehadiran peneliti selaku instrumen utama adalah sebagai berikut:

Manusia merupakan alat (instrumen) utama pengumpul data. Penelitian kualitatif menghendaki peneliti atau dengan bantuan orang lain sebagai alat utama pengumpul data. Hal ini dimaksudkan agar lebih mudah mengadakan penyesuaian terhadaap kenyataan-kenyataan yang ada dilapangan. ${ }^{8}$

Dalam penelitian kualitatif peneliti adalah pengumpul data, orang yang ahli dan memiliki kesiapan penuh untuk memahami situasi, peneliti juga sekaligus sebagai instrumen. Penelitian kualitatif disebut juga "penelitian subjektif" atau "penelitijan reflektif", peneliti melakukan pengujian sendiri secara kritis selama proses penelitian. ${ }^{9}$

Sebagaimana yang telah dijelaskan di atas bahwa peneliti sebagai peneliti bertindak sebagai instrumen utama dalam penelitian sekaligus dalam pengumpulan data dalam melakukan penelitian. Sehingga kehadiran peneliti merupakan sesuatu yang sangat penting dan mutlak pada lokasi yang dijadikan objek penelitian. Dan kehadiran peneliti memperoleh izin secara resmi yakni dengan cara mendapatkan surat izin dari pihak Institut Agama Islam Negeri Palu ( IAIN) Palu. Dan dengan izin tersebut peneliti melaporkan maksud kehadiran peneliti kepada kepala sekolah di sekolah SDN Inpres Bumi Bahari. Dengan tujuan agar peneliti mendapatkan izin untuk meneliti di sekolah SDN Inpres Bumi Bahari.

Data dan sumber data merupakan faktor penentu keberhasilan suatu penelitian. Dan suatu penelitian tidak dapat dikatakan bersifat ilmiah bila tidak ada data yang dapat dipercaya. Karena jenis penelitian ini merupakan penelitian kualitatif.

\footnotetext{
${ }^{8}$ S. Margono, Penelitian Pendidikan, (Jakarta: Rineka Putra Cipta, 2000), h.38.

${ }^{9}$ Sudaryono, Metodologi Penelitian, (Cet. 1; Jakarta: RajaGrafindo Persada, 2017), 76.
} 
Menurut Suharsini Arikunto bahwa "sumber data dalam penelitian adalah subyek dari mana data diperoleh". ${ }^{10}$ Pencatatan sumber utama melalui wawancara atau pengamatan merupakan hasil usaha gabungan dari kegiatan melihat, mendengar, dan bertanya. Manakah ketiga diantara yang dominan, jelas akan bervariasi dari satu waktu kewaktu lainya dan satu situasi kesituasi lainya. Aktivitas penulis tidak akan terlepas dari keberadaan data yang merupakan bahan baku informasi untuk memberikan gambaran spesifik mengenai objek penelitian.

Data adalah fakta empiris yang dikumpulkan oleh peneliti untuk kepentingan memecahkan masalah atau menjawab pertanyaan penelitian. Data penelitian di dapat dari berbagai sumber yang dikumpulkan dengan menggunakan berbagai teknik selama kegiatan berlangsung. ${ }^{11}$

Menurut Burhan Bungin "ada dua jenis sumber data yang biasanya digunakan dalam penelitian sosial yaitu sumber data primer dan sumber data sekunder". ${ }^{12}$ Sedangkan menurut S. Nasution, sumber data dalam penelitian ini ini dikategorikan dalamdua bentuk yaitu ." data primer dan data sekunder". Data primer yaitu jenis data yang diperoleh lewat pengamatan langsung dilapangan. Sedangkan data sekunder adalah data penunjang yang merupakan data pelengkap yang diperoleh melalui literatur-literatur, dokumen-dokumen, dan lain-lain seperti statistik yang telah tersedia sebagai sumber data tambahan bagi keperluannya. ${ }^{13}$

\section{Data primer}

Husen Umar mengemukakan bahwa pengertian data primer dengan menyatakan bahwa data primer merupakan data yang didapat dari sumber pertama, baik individu atau perorangan, seperti hasil wawancara atau hasil penelitian kuesioner yang biasa dilakukan oleh pendidik". ${ }^{14}$ Data primer yaitu data diperoleh lewat pengamatan langsung dan wawancara melalui narasumber dan atau informasi yang dipilih. Adapun sumber atau informasi penelitian ini adalah guru pendidikan Madrasah Ibtidayah di sekolah SDN Ipres Bumi Bahari.

2. Data sekunder

Datayang dihimpun selanjutnya adalah data sekunder, untuk lebih memperjelas pengertian data sekunder ini, penulis kembali meneruskan kutipan dari Husen Umar, sebagai berikut: Data sekunder merupakan data primer yang telah diolah lebih lanjut dan disajikan baik oleh pengumpul data primer atau oleh pihak lain. Misalnya dalam bentuk tabel atau diagram. Data sekunder ini digunakan oleh peneliti untuk diproses lebih lanjut. ${ }^{15}$

\footnotetext{
${ }^{10}$ Suharsini Arikunto, Prosedur Penelitian Suatu Pendekatan Praktek ( Ed. revisi , Cet. XII; Jakarta: 2002), 107.

11 Trianto, Pengantar Penelitian Pendidikan Bagi Pengembangan Profesi Pendidikan dan Tenaga Kependidikan (Cet 1: Jakarta : Kencana, 2010), 279.

${ }^{12}$ Burhan Bungin, Metode Penelitian Sosial, Faktor-faktor Kualitatif Dan Kuantitatif ( Cet 1: Surabaya : Air langga university press. 2001 ), 129.

${ }^{13}$ S. Nasution, Metode Research (Penelitian Ilmiah), (Jakarta: Bumi Aksara, 2004), 143

${ }^{14}$ Husen umar, Metode Penelitian Untuk Skripsi Dan Tesis Bisnis ( Cet 4: Jakarta :PT, Raja Grafindo Persada, 2001 ), 2.

15 Ibid, 46.
} 
Adanya data tersebut memudahkan penulis dalam mengumpulkan data yang dianggap perlu untuk menunjang dan memberikan keabsahan atau validnya suatu data dalam penelitian kualitatif itu sendiri.

Dalam peneliti, penggunaan metode yang tepat amat diperlukan untuk menentukan teknik data dan alat pengumpulan data yang akurat dan relevan. Keberadaan data mutlak diperlukan dalam sebuah penelitian untuk menjawab seluruh permasalahan di dalam penelitian, sangat membutuhkan data dari berbagai sumber. Dan pada tahap awal pengumpulan data, penulis melakukan studi pustaka terlebih dahulu dengan mencari data sebanyak mungkin dengan jalan membaca referensi atau buku-buku yang terkait dengan penelitian penulis selanjutnya menyusun rencanarencana penelitian berupa observasi, wawancara, dan dokumentasi. ${ }^{16}$

Pada hakekatnya, data bagi seorang penulis adalah sebagai alat atau dasar utama dalam pembuatan keputusan atau pemecahan masalah. Oleh karena itu, data yang diambil harus benar-benar memenuhi kriteria yang dijadikan alat dalam mengambil keputusan. Kriteria yang lebih sebagaimana yang dikemukakan oleh j.supranto dalam buku metode riset aplikasinya dalam pemasaran adalah: Data yang baik adalah data yang bisa dipercaya kebenaranya (reliable), tepat waktu (up to date) dan mencangkup ruang lingkup yang luas atau bisa memberikan gambaran tentang suatu masalah secara menyeluruh (comprehensive). ${ }^{17}$ Pada penelitian ini penulis menggunakan teknik pengumpulan data sebagai berikut :

\section{Observasi}

Observasi adalah metode ilmiah yang dapat diartikan sebagai pengamatan melalui pemusatan perhatian terhadap suatu objek dengan menggunakan alat indra. ${ }^{18}$ Selain itu observasi yang dimaksud sebagai pengamatan dan pencatatan secara sistematika terhadap gejala yang tampak pada objek peneliti. Pengamatan dan pecatatan yang dilakukan terhadap objek ditempat terjadi atau berlangsungnya peristiwa, sehingga observasi berada bersama objek yang diselidiki, dalam hal ini untuk memperoleh data yang akurat, valid dan memadai peneliti akan melakukan pengamatan secara langsung pada lokasi peneliti. ${ }^{19}$ Dalam hal ini penulis melakukan pengamatan secara lansung terhadap guru dan para peserta didik di sekolah SDN Inpres Bumi Bahari. Dengan memperhatikan cara guru mengolah hasil pembelajaran dan cara belajar mereka ketika mengikuti kegiatan belajar mengajar di sekolah.

2. Wawancara

Lexy J. Maleong dalam buku Metodologi Penelitian Kualitatif mengemukakan bahwa wawancara adalah percakapan dengan maksud tertentu. Percakapan ini dilakukan oleh dua pihak yaitu pewawancara (interviewer) yang mengajukan

\footnotetext{
${ }^{16}$ Husaini Usman, Metodologi Penelitian Sosial (Cet. 4: Jakarta : Bumi Aksara, 2001), 73.

${ }^{17}$ J. Supranto, Metode Riset Aplikasinya dalam Pemasaran ( Ed. 3: Jakarta : Fakultas Ekonomi UI, 1981), 2.

${ }^{18}$ S. Margono, Metode Penelitian Pendidikan, 158.

${ }^{19}$ S. Nasution, Metode Research (Penelitian Ilmiah), 144.
} 
pertanyaan dan yang diwawancara memberikan jawaban atas pertanyaan itu. ${ }^{20}$ Dalam pelaksanaannya tehnik wawancara dapat dibedakan kedalam dua tehnik yaitu tehnik wawancara langsung yaitu tehnik pengumpulan data dengan menggunakan pedoman wawancara sebagai alatnya, sedangkan wawancara tidak langsung yaitu menggunakan alat pengumpulan data berupa ceklist. Metode ini dilakukan oleh penulis untuk memperoleh data tentang penerapan metode eksperimen dalam pembelajaran IPA di sekolah SDN Inpres Bumi Bahari dengan melakukan wawancara langsung kepada guru mata pelajaran Ilmu Pengetahuan Alam (IPA) serta peserta didik itu sendiri guna melengkapi data.

3. Dokumentasi

Dokumentasi adalah teknik pengumpulan data yang dimana data itu diperoleh melalui dokumen-dokumen. ${ }^{21}$ Selain itu dokumentasi merupakan teknik pengumpulan data dengan menela dokumen penting yang menunjang kelengkapan data dan dalam teknik pengumpulan data ini penulis melakukan penelitian dengan menghimpun data relevan dari sejumlah dokumen resmi atau arsip penting yang dapat menunjang kelengkapan penelitian. Metode dokumentasi digunakan untuk memperoleh data perkembangan pembelajaran, merekam hasil wawancara, dan pengambilan gambar serta melihat aktifitas guru di SDN Inpres Bumi Bahari Ilmu Pengetahuan Alam dalam melakukan pengelolaan hasil belajar peserta didik.

- Setelah jumlah data dan keterangan penulis kumpulkan, maka langkah selanjutnya adalah menganalisis data. Adapun analisis data yang digunakan dalam penelitian ini adalah analisis kualitatif, yang terdiri dari tiga jenis yaitu sebagai berikut:

1. Reduksi data adalah proses untuk menyusun data dalam bentuk uraian konkrit dan lengkap sehingga data yang disajikan dalam suatu bentuk narasi yang utuh. Mattew B Miles dan A. Michel Huberman menjelaskan Reduksi data adalah sebagai proses pemilihan, pemutusan, perhatian pada penyederhana, pengabstrakan dan transformasi data "kasar" yang muncul dari catatan-catatan tertulis dilapangan. Sebagaimana kita ketahui, reduksi data berlangsung terus menerus selama proyek yang berorientasi kualitatif berlansung. ${ }^{22}$ Reduksi data diterapkan pada hasil observasi, wawancara dan dokumentasi dengan mereduksi kata-kata yang dianggap penulis tidak signifikan bagi penelitian ini. Artinya penyederhanaan kembali serta memfokuskan kembali dan mengubah data kasar dari catatan lapanganya.

2. Penyajian data yaitu setelah jumlah data dikumpulkan dengan mengambil beberapa data dari jumlah keseluruhan data yang tersedia. Selanjutnya adalah menyajikan kedalam inti pembahasan yang dijabarkan pada hasil penelitian dilapangan.

\footnotetext{
${ }^{20}$ Lexy J. Maleoang, Metode Penelitian Kualitatif, ( Bandung : Remaja Rosdakarya, 2002),10.

${ }^{21}$ Amirul Hadi dan Hariyono, Metode Penelitian Pendidikan, (Bandung : CV. Pustaka Setia, 1998), 10.

${ }^{22}$ Mattew B Miles dan A. Michel Huberman, Analisis Data Kualitatif, Buku tentang Metode-Metode Baru ( Cet. 1: Jakarta, UI-Press, 1992), 12.
} 
3. Verifikasi data yaitu pengambilan kesimpulan yang dilakukan oleh peneliti terhadap data tersebut. Sebagaimana dikemukakan oleh Mattew B. ${ }^{23}$ Miles yakni kegiatan anlisis yang paling penting adalah menarik kesimpulan dari verifikasi. Dari permulaan data seorang penganalisis kualitatif mulai mencari arti benda-benda, mencatat keteraturan, pola-pola, penjelasan konfigurasikonfigurasi yang mungkin alur sebab akibat dari proposi. Teknik verifikasi dalam penelitian ini dilakukan dengan tiga cara, yaitu: (a). Deduktif, yaitu analisis yang berangkat dari data yang bersifat umum untuk mendapatkan kesimpulan yang bersifat khusus. (b) Induktif, yaitu dari analisis yang berangkat dari data yang bersifat khusus untuk mendapatkan kesimpulan yang bersifat umum. (c) Kompratif, analisis yang membandingkan beberapa data untuk mendapatkan kesimpulan tentang persamaan maupun perbedaan.

Untuk mendapatkan keabsahan data diperlukan teknik pemeriksaan. Pelaksanaan tekhnik pemeriksaan didasarkan pada sejumlah kriteria. Ada empat kriteria keabsahan data yang bisa digunakan yaitu: Derajat kepercayaan (credibility), keteralihan (transferability), keberuntungan (dependability), dan kepastian (confirmanbility). ${ }^{24}$

Pengecekan keabsahan data dalam penelitian kualitatif yang dibutuhkan untuk mendapatkan validitas dan tingkat kredibilitas data yang diperoleh. Dan dalam penelitian ini penulis mengecek keabsahan data dengan memanfaatkan sesuatu diluar data sebagai pembanding dari data yang diperoleh. Untuk lebih jelasnya penulis menguraikannya sebagai berikut:

1. Derajat kepercayaan ; maksudnya peneliti menunjukan hasil-hasil penemuan dengan jalan pembuktian pada kenyataan yang sedang diteliti.

2. Keteralihan; maksudnya generalisasi suatu penemuan dapat berlaku atau diterapkan pada semua konteks dalam populasi yang sama atas dasar penemuan yang diperoleh pada sampel yang secara refresentatif mewakili populasi.

3. Keberuntungan; maksudnya realibitas atau dapat diukur, artinya penelitian yang dilakukan berulang-ulang tetapi secara esensi hasilnya sama

4. Kepastian; maksudnya ada kesempatan antara subjek-subjek yang diteliti. Pengecekan keabsahan data juga dimaksudkan agar tidak terjadi keraguan terhadap data yang diperoleh baik itu dari penulis sendiri maupun para pembaca sehingga dikemudian hari nantinya tidak ada yang dirugikan terutama penulis yang telah mencurahkan segala tenaganya dalam penyusunan karya ilmiah ini.

Pengecekan keabsahan data diterapkan dalam penelitian ini agar data yang diperoleh terjamin validitasnya dan kredibilitasnya. Dan dalam hal ini penulis mengadakan peninjauan kembali, apakah fakta sebagai analisis dari seluruh data yang diperoleh memang benar-benar dan terjadi disuatu lokasi tempat diadakanya penelitian, yaitu di sekolah SDN Inpres Bumi Bahari.

\footnotetext{
${ }^{23}$ Ibid

${ }^{24}$ Lexy J. Maleong, Metodologi Penelitian Kualitatif(Bandung: Remaja Rosda Karya, 2003), 173
} 


\section{HASIL PENELITIAN DAN PEMBAHASAN}

Pada tanggal 15 juli 2019, penulis melakukan observasi di dalam proses pembelajaran IPA (metode eksperimen) di dalam kelas. Observasi ini bertujuan untuk mengetahui bagaimana langkah-langkah guru mata pelajaran dalam menerapkan metode eksperimen dalam pembelajaran IPA tersebut. Dari hasil obsevasi, dapat di ketahui bahwa metode eksperimen itu sendiri memiliki beberapa tahapan dalam pelaksanaannya.

1. Tahap persiapan

Tahapan pertama ialah tahapan persiapan. Pada tahap ini, hal-hal yang dilakukan guru mata pelajaran antara lain:

a. Merumuskan tujuan yang harus dicapai oleh peserta didik pada metode eksperimen pembelajaran IPA. Tujuan pembelajaran yang akan dicapai adalah peserta didik dapat melakukan fotosintesis pada tumbuhan cemangi melalui metode eksperimen.

b. Menentukan hasil pengamatan dari tumbuhan cemangi yang dapat di amati oleh peserta didik dalam fotosintesis.

c. Menyampaikan dan menjelaskan materi tentang fotosintesis.

d. Menyiapkan dan membagikan soal- eksperimen pada fotosintesis.

e. Menyampaikan dan menjelaskan metode eksperimen tentang materi fofosintesis yang akan di amati oleh peserta didik.

f. Menjelaskan hasil pengamatan fotosintesis dari tumbuhan cemangi pada peserta didik.

2. Tahap pelaksanaan

Dalam tahapan pelaksanaan, hal-hal yang dilakukan oleh guru mata pelajaran IPA materi fotosintesis anatara lain:

a. Mempersiapkan alat dan bahan seperti: polibet,tanah,dan tumbuhan cemangi.

b. Menanam tumbuhan cemangi pada alat dan bahan yang sudah disiapkan.

c. Melakukan perbedaan metode eksperimen pada materi fotosintesis dengan tumbuhan cemangi.

d. Mengamati perbedaan tumbuhan cemangi pada fotosintesis.

e. Dan melakukan uji coba dari hasil pengamatan tumbuhan cemangi pada fotosintesis.

3. Tahap penutupan

Adapun kegiatan yang dilakukan oleh guru pada mata pelajaran IPA antara lain:

a. Mengevaluasi hasil pengamatan praktek fotosintesis pada tumbuhan cemangi.

b. Memberikan pengulangan hasil pengamatan fotosintesis peserta didik pada tumbuhan cemangi.

Hal ini sesuai dengan pernyataan salah satu guru wali kelas bahwa: Metode eksperimen adalah metode yang sangat tepat diterapkan dalam pembelajaran IPA. Akan tetapi sebelum diterapkannya metode tersebut, guru harus mempersiapkan perangkat pembelajaran, menguasai materi, dan merumuskan tujuan yang hendak 
dicapai dalam pembelajaran. Hal ini di maksudkan untuk mempermudah guru dalam menyampaikan materi. $^{25}$

Cara penyajian materi dengan menggunakan metode eksperimen dalam proses pembelajaran ialah penyampaian materi biasanya diawali dengan merumuskan tujuan yang hendak dicapai, menentukan hasil pengamatan dan menyampaikan simpulan dari pengamatan pada materi ajar khususnya fotosintesis pada tumbuhan cemangi. Senada dengan hal tersebut salah satu peserta didik yang berada di SDN Inpres Bumi Bahari mengatakan bahwa: Ketika diterapkannya metode eksperimen dalam pembelajaran IPA, itu sangat bagus memudahkan kami dalam melakukan eksperimen atau percobaan pada sebuah tumbuhan yang ada kaitannya dengan materi IPA. Selain itu kami tidak hanya mengetahui secara teori pelajaran yang diberikan oleh guru melainkan kami dapat melihat langsung tanaman yang kami pelajari. ${ }^{26}$

Berdasarkan penjelasan diatas, dihubungkan dengan fakta lapangan tentang penerapan metode eksperimen dalam pembelajaran IPA di SDN Inpres Bumi Bahari, penulis mendapatkan hasil penelitian bahwa tahapan-tahapan dalam penerapan metode eksperimen dalam pembelajaran IPA sebagai berikut:

1. Tahap persiapannya ialah menyiapkan materi dan tujuan pembelajaran yang harus dicapai dalam proses pembelajaran khususnya pelajaran IPA. Hal ini dimaksudkan agar penerapan metode eksperimen dalam proses pembelajaran lebih efektif

2. Tahap pelaksanaannya ialah penyampaian materi kepada peserta didik dan mendemostrasikan materi ajar misalnya pengamatan sfotosintesis, latihan/eksperimen. Hal ini dilakukan oleh guru sebelum memberikan tugas kepada peserta didik untuk mengamati fotosintesis pada tumbuhan cemangi.

3. Tahap penutupan ialah perbaikan kesalahan dari hasil pengamatan. Tindakan ini dilakukan oleh guru untuk melihat kemandirian para peserta didik dalam melakukan pengamatan atupun percobaan pada materi fotosintesis dan melihat ketercapaian tujuan pembelajaran pada materi tersebut.

Setelah di terapakan metode eksperimen dalam pembelajaran IPA, guru melakukan evaluasi metode eksperimen pada materi fotosintesis hasil dari pengamatan tumbuhan cemangi. Penulis telah melampirkan hasil pengamatan peserta didik pada akhir skripsi ini. Dari hasil pengamatan tersebut, dapat diketahui bahwa peserta didik tidak dapat memenuhi kriteria ketuntasan minimum sehingga perlu dilakukan uji coba hasil pengamatan tersebut. Hal ini menjadi tanda tanya bagi penulis apakah ada kendala atau solusi yang mereka hadapi selama penerapan metode eksperimen dalam pembelajaran IPA di SDN Inpres Bumi Bahari.

Seperti yang telah disebutkan bahwa peserta didik yang nilainya berada di bawah kriteria ketuntasan minimum. Hal ini mendorong penulis untuk melakukan

${ }^{25}$ Nengah Sutiasa, Guru kelas 4, “Wawancara” Sekolah Tanggal 16 juli 2019

${ }^{26}$ Siko, Peserta Didik SDN Inpres Bumi Bahari, “wawancara” Sekolah Tanggal 16 juli 2016 
wawancara yang bertujuan untuk mengetahui penyebab ke tidak tuntasan nilai peserta didik tersebut, serta melihat sejauh mana dampak dari Penerapan Metode Eksperimen dalam Pembelajaran IPA di SDN Inpres Bumi Bahari. Dari hasil wawancara, diketahui bahwa terdapat beberapa kendala dan solusi pada Penearpan Metode Eksperimen dalam Pembelajaran IPA di SDN Inpres Bumi Bahari. Berikut ini penulis sajikan kendala dan solusi yang dapat ditemui dengan cara mengatasinya:

1. Kendala yang dihadapi pada penerapan metode eksperimen dalam pembelajaran IPA di SDN Inpres Bumi Bahari.

Adapun kendala yang dihadapi oleh guru di SDN Inpres Bumi Bahari sesuai dengan hasil wawancara yang di ungkapkan oleh salah satu guru kelas bahwa:

Dalam proses pembelajaran di dalam kelas peserta didik kurang memperhatikan penjelasan guru dengan baik dan serius. Para peserta didik tersebut banyak bermain, sehingga tidak dapat menangkap dengan baik dan serius penjelasan dari guru meskipun materi tersebut telah dijelaskan secara berulang-ulang. Hal ini menjadi salah satu kendala dalam proses pembelajaran IPA melalui metode eksperimen. Namun, cara yang dapat ditempuh untuk mengetahui kendala ini ialah dengan memberikan waktu tambahan khusus bagi peserta didik yang belum mengerti dan kurang-nya penjelasan guru terhadap peserta didik. ${ }^{60}$

2. Solusi yang dilakukan oleh guru ketika mendapat kendala dalam menerapkan metode eksperimen dalam pembelajaran IPA di SDN Inpres Bumi Bahari.

Adapun solusi yang digunakan untuk mengatasi berbagai macam kendala yang dihadapi guru dalam menerapkan metode eksperimen di SDN Inpres Bumi Bahari sesuai dengan hasil wawancara yang di ungkapkan oleh salah satu guru kelas bahwa:

Dalam proses belajar mengajar antara guru dan peserta didik meminta kerja sama-nya agar supaya ketika guru menjelaskan materi atau pembelajaran peserta didik dapat dengan mudah menangkap atau memahami materi pemebelajaran yang guru jelaskan kepada peserta didik. Hal ini juga menjadi solusi dalam pelaksanaan metode eksperimen dalam pembelajaran IPA di dalam kelas. Dalam kelas peserta didik memahami kesulitan tata cara menerima metode eksperimen dalam pembelajaran IPA di SDN Inpres Bumi Bahari, tentang materi fotosintesis. Dan adapun peserta didik yang memahami metode eksperimen ini melalui fotosintesis dengan mudah dan menyenangkan, karena dari hasil pembelajaran metode eksperimen dalam pembelajaran IPA ini, peserta didik dapat mengetahui dan bisa, yang sebelumnya belum tau menjadi tau sehingga peserta didik dapat memetik hasil dari fotosintesis (metode eksperimen) yang dilakukan dengan cara uji coba menanam tumbuh-tumbuhan, dan bisa juga untuk memperindah halaman rumah atau sekitarnya. ${ }^{27}$

\footnotetext{
${ }^{27}$ Nengah Sutiasa, Guru kelas 4, “Wawancara” Sekolah Tangsgal 16 juli 2019
} 
Hasil wawancara yang telah diuraikan penuliss menyimpulkan bahwa sikap profesional guru akan mampu melahirkan pengajaran yang bermutu, sebab adanya sikap profesional yang dimiliki guru maka apapun masalah atau kendala yang dihadapi dalam proses pembelajaran dapat teratasi. Misalnya membangun kerjasama yang baik dengan peserta didik pada proses pembelajaran artinya ada respon dari peserta didik pada proses pembelajaran dan pemahaman peserta didik terhadap materi yang diajarkan.

\section{KESIMPULAN}

Berdasarkan uraian-uraian yang di kemukakan pada bab sebelumnya maka pada bab ini penulis akan mengemukakan beberapa kesimpulan yaitu sebagai berikut.: (1) Metode eksperimen dalam pembelajaran IPA di SDN Inpres Bumi Bahari, telah dilakukan melalui beberapa tahapan. Tahapan pertama ialah tahap persiapan. Dalam tahapan persiapan, guru mata pelajaran harus merumuskan tujuan pembelajaran yang hendak dicapai oleh pesert didik dalam pembelajaran IPA (fotosintesis). Hal ini dimaksudkan agar penerapan metode eksperimen dalam proses pembelajaran lebih efektif dan peserta didik aktif selama proses pembelajaran berlangsung. Tahapan kedua yaitu tahap pelaksanaan. Tahap pelaksanaan meliputi penjelasan materi, pendemostrasian unjuk kerja (pre-eksperimen) dan pengamatan fotosintesis pada tumbuhan cemangi. Dalam tahap ini guru harus dengan teliti memerintahkan peserta didiknya mengamati baik-baik fotosintesis yang ada pada tumbuhan cemangi. Tahap ketiga yakni tahap penutupan. Dalam tahap penutupan, guru memperbaiki hasil pengamatan peserta didik yang belum mengati secara serius dan secara baik-baik pada saat pengamatan berlangsung. Tahap penutupan dapat pula menjadi perbaikan kesalahan dari hasil pengamatan. Tindakan ini dilakukan oleh guru untuk melihat kemandirian para peserta didik dalam melakukan pengamatan ataupun percobaan pada materi fotosintesis dan melihat ketercapaian tujuan pembelajaran pada materi tersebut. (2) Adapun kendala yang dapat ditemui pada penerapan metode eksperimen dalam pembelajaran IPA di SDN Inpres Bumi Bahari. Pertama, kurang mengerti dan kurangnya perhatian atau penjelasan guru pada peserta didik dalam mengikuti proses pembelajaran metode eksperimen (fotosintesis). Solusi atau cara yang dapat ditempuh untuk mengatasi kendala tersebut ialah dengan kerja sama antara guru dan peserta didik, agar supaya peserta didik lebih mudah memahami pembelajaran atau materi yang di jelaskan oleh guru ke pada peserta didiknya. Kedua, kemampuan peserta didik yang berbeda-beda dalam memahami atau menagkap materi pembelajaran yang dijelaskan oleh guru ke pada peserta didik. Adapun peserta didik yang kurang memahami pembelajaran metode eksperimen (fotosintesis). Hal yang dapat dilakukan oleh guru untuk mengatasi permasalahan tersebut ialah dengan memberikan perhatian yang lebih ke pada peserta didik yang belum memahami metode eksperimen (fotosintesis) dan memberikan waktu belajar 
tambahan ke pada peserta didik, khususnya peserta didik yang belum memahami metode eksperimen (fotosintesis).

\section{SARAN}

Setelah penulis melakukan penelitian mengenai penerapan metode eksperimen dalam pembelajaran IPA di SDN Inpres Bumi Bahari, maka ada beberapa saran yang penulis kemukakan melalui tulisan ini yaitu sebagai berikut: (1) Bagi guru, metode eksperimen merupakan salah satu alternatif yang dapat diterapkan dalam pembelajaran IPA. Guru dapat pula menggunakan praktek uji coba bercocok tanam tumbuh-tubuhan dalam menjelaskan materi fotosintesis tersebut. (2) Bagi para peserta didik agar lebih giat dan tekun dalam mendalami mata pelajaran IPA khususnya pada hasil pengamatan dari fotosintesis, agar peserta didik dapat memperaktekkan uji coba bercocok tanam pada tumbuh-tumbuhan dirumah atau alam sekitarnya. (3) Kepada kepala sekolah SDN Inpres Bumi Bahari seluruh stafstaf atau jajarannya, agar terus berupaya untuk memenuhi segala fasilitas dan sarana prasarana yang belum ada yang dapat menunjang keberhasilan pembelajaran terutama dalam pembelajaran IPA.

\section{DAFTAR PUSTAKA}

Amirul Hadi dan Hariyono, Metode Penelitian Pendidikan, (Bandung : CV. Pustaka Setia, 1998), 10.

Arif Rohman, Memahami Ilmu Pendidikan, (Yogyakarta: CV. Aswaja Pressindo, 2013),hlm. 4.

Asih Widi Wisudawati dan Eka Sulistiyo Wati, Metodologi Pembelajaran IPA, (Jakarta: Bumi Aksara, 2014), 156

Agus, Sugiyono, Pembelajaran IPA MI, (Surabaya: Lapis PGMI, 2009) 10

Bambang Tjiptudi, Rangkuman Tata Bahasa Indonesia (Cet. III; Jakarta: 1985), 34

Burhan Bungin, Metode Penelitian Sosial, Faktor-faktor Kualitatif Dan Kuantitatif ( Cet 1: Surabaya : Air langga university press. 2001 ), 129.

Disadur dari Trianto Al-Tabny, Desain Pengembangan Pembelajaran Tematik Bagi anak Usia Dini TK/RA dan Anak Kelas Awal SD, (Jakarta: Prenadamedia Group, 2015), 199-200

Desmita. Psikologi Perkembangan Peserta Didik, (Bandung: PT. Remaja Rossdakarya, 2014), 97

Djamarah, , Strategi Belajar Mengajar, (Jakarta: Rineka Cipta, 2010)

Husen umar, Metode Penelitian Untuk Skripsi Dan Tesis Bisnis ( Cet 4: Jakarta :PT, Raja Grafindo Persada, 2001 ), 2.

HendroDarmodjo, Jenny R.E Kaligis, Pendidikan Ipa 2, (Jakarta: Depdikbud 1993), 12.

Husaini Usman, Metodologi Penelitian Sosial (Cet. 4: Jakarta : Bumi Aksara, 2001),73. 
J. Supranto, Metode Riset Aplikasinya dalam Pemasaran ( Ed. 3: Jakarta : Fakultas Ekonomi UI, 1981), 2.

Lexy J. Moleang, Metode Penelitian Kualitatif, ( Bandung : Remaja Rosdakarya, 2002), 10.

Mahfudin Salahudin, Metodologi pendidikan agama(Cet; Ke II. Surabaya: Bina Ilmu. 2001), 29

MC. Donald, Interaksi dan motivasi (Jakarta : Raja Grafindo Persada, 2003), 73

Mattew B Miles dan A. Michel Huberman, Analisis Data Kualitatif, Buku tentang

Metode-Metode Baru ( Cet. 1: Jakarta, UI-Press, 1992), 12.

Nana Syaodih Sukmadinata, Metode Penelitian Pendidikan( Cet. 8: Bandung: Pt

Remaja Rosdakarya, 2012), 60

Nengah Sutiasa, dalam kelas, "wawancara”, tanggal 16 juli 2019

Puji, L, Perkembangan Kognitif Anak Usia Sekolah Dasar, Banten: Hera Lestari Mikarsa, 2012, 2.4

Rahmayanti, dalam kelas, "wawancara” tanggal 20 juli 2019

Rostiyah, Strategi Belajar Mengajar, (Jakarta: Rineka Cipta, 2001), 80

Siko, siswa SDN Inpres Bumi Bahari, “wawancara”, ruang kelas, tanggal 16 juli 2019

Sugiono, Metode Penelitian Pendidikan (Cet. 20; Bandung: Alfabeta, 2014), 22.

Sudaryono, Metodologi Penelitian, (Cet. 1; Jakarta: RajaGrafindo Persada, 2017), 76.

Sunaryo, Landasan-Landasan Pendidikan Sekolah Dasar, (Jakarta: Departemen Pendidikan dan Kebudayaan, 2010) hal 538

Suharsini Arikunto, Prosedur Penelitian Suatu Pendekatan Praktek (Ed. revisi, Cet. XII; Jakarta: 2002), 107.

Sri Sulistyorini, Pembelajaran Ipa Dasar, (semarang: Tiara Wacana, 2007), 8

Syaiful Sagala, Konsep dan Makna Pembelajaran: Untuk Membantu Memecahkan

Problematika Belajar dan Mengajar, (Bandung: CV. Alfabeta, 2005), 220

S. Margono, Metode Penelitian Pendidikan, 158

S. Nasution, Metode Research (Penelitian Ilmiah), 144

Trianto, Pengantar Penelitian Pendidikan Bagi Pengembangan Profesi Pendidikan dan Tenaga Kependidikan (Cet 1: Jakarta : Kencana, 2010), 279.

Usman Samatowa, Pembelajaran IPA di Sekolah Dasar, (Jakarta: Indeks 2006), 146

W. Sanjaya, Strategi Pembelajaran Berorintasi Standar Proses Pendidikan, (Jakarta: Kencana, 2009), 149

Wahyana, Model Pembelajaran Terpadu Konsep, Strategi dan Implementasinya dalam KTSP, (Jakarta: Bumi Aksara, 2004), 41 